Plant Tissue Cult. \& Biotech. 22(1): 27-32, 2012 (June)

$\overline{\text { PTC\&B }}$

\title{
Estimation of Ascorbic Acid Content in Prosopis cineraria (L.) Druce Cultivar K1
}

\author{
Ruchi Nag, Arjit Chaturvedi ${ }^{1}$, Amit Sharma ${ }^{1}$, Shashi Bidawat ${ }^{1}$, \\ L. K. Pareek and T. N. Nag ${ }^{1}$
}

Department of Botany, University of Rajasthan, Jaipur, India

Key words: Callus culture, Ascorbic acid, Prosopis cineraria

\begin{abstract}
The callus tissues of Prosopis cineraria (L.) Druce established and maintained for a period of eight months on MS supplemented with $2 \mathrm{mg} / \mathrm{l}, 2$, 4-D and its plant parts were used for estimation of ascorbic acid. The tissue thus grown was transferred to fresh MS and MS singly supplemented with $0.5,1,1.5$ and 2\% of glucose. The growth indices and ascorbic acid contents in tissues were determined at time interval of two, four, six and eight weeks. Six weeks old tissue cultures showed an increase in the amount of endogenous ascorbic acid as well as growth indices in all the samples. The cultures grown on MS supplemented with $1.5 \%$ of glucose showed maximum ascorbic acid content (174.23 mg/100 gdw) and growth index (19.68). Tissues reared with different concentration of glucose showed remarkably high content of ascorbic acid content as compared to control and plant parts.
\end{abstract}

\section{Introduction}

Nutritional information is used increasingly by public agencies and agricultural industries to promote fresh produce. Consumers are looking for variety in their diets and are aware of the health benefits of fresh fruits and vegetables. Of special interests are food source rich in antioxidant vitamins (ascorbic acid). In addition to meeting nutrient intake levels, greater consumption of fruits and vegetables is associated with stroke, and cancers of the mouth, pharynx, oesophagus, lungs, stomach, and colon. Ascorbic acid is essential for the normal function of living cells and many enzymatic reactions in humans (Marcus and Couston 2000) and is obtained from dietary sources such as vegetables and fruits and synthetic vitamin C. Its deficiency typically causes abnormalities in bones,

${ }^{1}$ Plant Tissue Culture and Biotechnology Laboratory, M. N. Institute of Applied Sciences (MGS University, Bikaner), Bikaner-334022, India. <ptaci2011tn@gmail.com>,

$<$ arjitchaturvedi@yahoo.co.in>. 
teeth and scurvy. Apart from its role in nutrition, ascorbic acid acts as an antioxidant to protect the natural flavour and colour of many foods (Barbara 1984, Williams 1989). Many of desert plant fruits appear to be food sources of ascorbic acid.

Prosopis cineraria (Mimosaceae) locally called Khejri, is a boon to the people due to its myriad virtues. It distributes discontinuously in dry and semidry regions. This tree provides fodder, fuel, food, timber and also has nitrogen fixing ability with micro symbiotic affinity. Its unripped pods (sangri) are used for preparation of curries and pickles (Khasgiwal et al. 1969). This plant is used in pregnancy as a safeguard against miscarriage. The smoke of the leaves is good for eye troubles. The bark is used as a remedy for rheumatism, cough, common cold, asthma and scorpion sting (Rastogi and Mehrotra 1995 and Bhatacharjee 2001).

Endogenous free ascorbic acid has been reported in leaves of Oldenlandia corymbosa and Dissotis rotundifolia (Okeri and Alonge 2006), Brassica oleracea (Ahmed and Beigh 2009), Hibscus sabdarriffa and Lactuca sativa (Sarkiyayi and Ikioda 2010). Its endogenous production and exogenous effect have also been studied in plant tissue culture (Taygi and Nag 2002). As fruit (sangari) of $P$. cineraria is among widely consumed vegetables in arid zone of India and to authors' knowledge there has been no systematic study on the antioxidant constituents of sangari, the aim of the present study was to quantify the amount of ascorbic acid content in various parts and callus cultures of $P$. cineraria to see if the consumption of this plant will provide the recommended daily intake and also to find out whether the callus has higher amount of ascorbic acid content.

\section{Material and Methods}

Prosopis cineraria (L.) Druce plant parts such as root, shoots, pods with seeds and pods without seeds as identified and authenticated by taxonomist, Central Institute for Arid Horticulture, Bikaner (Rajsthan) India, were collected at their luxuriant growth, dried, powdered and used for the estimation of ascorbic acid content.

Seeds sterilized for $2-3 \mathrm{~min}$ in $0.1 \% \mathrm{HgCl}_{2}$ solution, rinsed with sterile distilled water were placed on paper bridges. Leaves and hypocotyls excised from aseptically grown 15 - 20 days old seedlings were taken as explants and cultured on MS supplemented with $2 \mathrm{mg} / \mathrm{l}$ 2,4-D. The callus tissues were maintained for 8 months by frequent subculturing at $26 \pm 2{ }^{\circ} \mathrm{C}, 55 \%$ relative humidity under light condition (3000 Lux). Media used throughout this study were supplemented with $3 \%$ sucrose and $0.8 \%$ agar. The $\mathrm{pH}$ was adjusted to 5.80 
\pm 0.02 with $1 \mathrm{~N} \mathrm{NaOH}$ or $0.1 \mathrm{~N} \mathrm{HCl}$ before autoclaving at $121^{\circ} \mathrm{C}$ and $15 \mathrm{lb}$ psi for 20 min. Further, glucose $(0.5,1,1.5$ and $2 \%)$ was singly supplemented in to medium and the callus tissues were harvested regularly at their transfer ages of 2, 4, 6 and 8 weeks and growth indices (GI) were calculated in each case on wet weight basis.

Cultures as well as different plant parts were weighed, crushed in ice cold $\mathrm{CO}_{2}$ saturated water and the extract was made to a definite volume. Three $\mathrm{ml}$ of extract was mixed with an equal volume of buffered metaphosphoric acid, $\mathrm{pH}$ 3.6. Two $\mathrm{ml}$ aliquot of this solution was mixed with $5 \mathrm{ml}$ distilled water and the turbidity produced was adjusted to zero with UV-VLS spectrophotometer-119. Another $2 \mathrm{ml}$ aliquot was then mixed with $5 \mathrm{ml}$ of 2,6 dichlorophenol indophenol, prepared by dissolving $5 \mathrm{mg}$ in $100 \mathrm{ml}$ of distilled water at $80^{\circ} \mathrm{C}$ and the optical density measured by UV-VLS spectrophotometer-119 set at $546 \mathrm{~nm}$ against blank (Chinoy 1962). Five replicates have been taken for each plant part.

The ascorbic acid content presents in $1 \mathrm{ml}$ of the original extract was obtained by using the regression formula:

$\mathrm{Y}=0.113-(0.14 \times \mathrm{OD})$,

where $\mathrm{Y}=$ Concentration of ascorbic acid in $\mathrm{mg}$.

$\mathrm{OD}=$ Optical density .

From the contents of $1 \mathrm{ml}$ if the extract the ascorbic acid content per $100 \mathrm{gm}$ dry weight was calculated as follows:

Free ascorbic acid $=(\mathrm{A} \times \mathrm{V}) / \mathrm{W} \times 1000 \times 100$,

where $\mathrm{A}=\mathrm{Y}=\mathrm{mg}$ AA $/ 1 \mathrm{ml}$ of original extract, $\mathrm{V}=$ Total volume of original extract (in $\mathrm{ml}$ ) and $\mathrm{W}=$ Weight of the plant sample $(\mathrm{mg})$ used for analysis.

\section{Results and Discussion}

The amount of ascorbic acid was found to be higher $(73.2 \mathrm{mg} / 100 \mathrm{gdw})$ in roots followed by shoots $(59.80 \mathrm{mg} / \mathrm{gdw})$ and minimum $(43.3 \mathrm{mg} / \mathrm{gdw})$ in the pods with seeds. The pods without seeds showed higher amount of ascorbic acid (52.96 $\mathrm{mg} / \mathrm{gdw})$ as compared with pods with seeds. The ascorbic acid concentration decreased from root to fruit. It supports the pervious findings that roots of some plant species synthesize some vitamins in sufficient quantities without being dependent upon the top for the supply of the same and also a downward translocation of ascorbic acid in plant (Singh et al. 1990 and Taygi and Nag 2002). Nag et al. (1986) reported maximum amount of endogenous ascorbic acid (150 mg/100 gdw) in the fruit of Fagonia cretica (desert plant) which was much higher than the maximum amount found in the fruits of $P$. cineraria. It can be suggested that plants of arid zone have biosynthetic 
potential to produce ascorbic acid at every stage of growth which is regarded as one of essential constituent of live stock feed and food for human.

Callus started appearing within 15 - 20 days of inoculation in the cultures. The best growth response for induction of unorganized cultures was shown by hypocotyl explants. The tissues were yellowish white and fragile in texture. Growth index of the tissues showed linear increase up to a period of six weeks (maximum growth) followed by a decline in 8 weeks. The tissues became brown after a period of six weeks which might be due to the accumulation of secondary metabolites. Ascorbic acid content increased from 2 to 6 weeks but declined in 8 weeks old tissues established on MS medium (control). Its concentration was greater in six weeks (55.63 mg/gdw) compared to $43.72 \mathrm{mg} / \mathrm{gdw}$ recorded in two weeks. However, Singh and Nag (1991) reported maximum ascorbic acid production in two weeks and minimum in 8 weeks old culture in Abutilon pannosum while Taygi and Nag (2002) reported maximum ascorbic acid in eight weeks old Vigna cultivars.

The tissues grown on glucose supplemented media were whitish and semicompact in texture. Growth indices showed a steady increase up to 6 weeks in all the samples, however in the tissues supplied with glucose, the growth was very rapid. The maximum GI 19.68 was found in tissues supplied with $1.5 \%$ glucose when compared with the control 8.10. In 2, 4, 6 and 8 weeks old cultures growth index was maximum in tissues in $1.5 \%$ glucose. However GI in glucose supplied tissues were higher as compared to the tissues grown on MS (control).

The ascorbic acid content was found to be maximum in six-week-old tissues. As the concentration of glucose into the medium increases, the amount of ascorbic acid also increases, but MS supplemented with $2.0 \%$ glucose showed a decline in ascorbic acid content; however its amount was still higher as compared with the tissue grown on MS and MS incorporated with other concentrations of glucose (0.5, 1.0 and 1.5\%). Maximum amount of ascorbic acid (174.23 mg /100 gdw) was found in six-week-old tissues grown on MS supplemented with $1.5 \%$ glucose while the minimum (141.77 mg $/ 100 \mathrm{gdw}$ ) was found in two weeks old cultures supplemented with $0.5 \%$ glucose (Table 1). The marked increase in ascorbic content in two-week-old glucose supplied tissues may be due to absorption of glucose from the medium by the callus and its conversion into the ascorbic acid via Dgluconic acid and L-gluconic acid (Isherwood and Mapson 1962). The rate of enhancement of ascorbic acid in 4, 6 and 8 weeks old tissues was low when compared with 2 weeks old tissue which might be due to its utilization in 
growth and development and also in synthesis of some secondary metabolites.

Effect of various concentrations of glucose on the endogenous production of ascorbic acid in tissue cultures of Lycium barbarum (Nag and Grover 1987), Abutilon pannosum (Singh and Nag 1991) has also been reported. It can be concluded that the potentialities of the tissues to produce ascorbic acid even in six weeks old tissues do not decrease. The data also reveal that the incorporation of the glucose into the medium might augment the synthesis of ascorbic acid in $P$. cineraria callus tissues and supports the previous findings that glucose acts as one of the precursors of ascorbic acid (Loewus and Kelly 1991).

Table 1. Effect of glucose on growth and production of ascorbic acid (mg/100 gdw) from tissue culture of $P$. cineraria (L.) Druce cv. K1.

\begin{tabular}{|c|c|c|c|c|c|}
\hline \multirow{2}{*}{$\begin{array}{l}\text { Age of } \\
\text { tissues }\end{array}$} & \multicolumn{3}{|c|}{ MS control } & \multicolumn{2}{|c|}{$\mathrm{MS}+0.5 \% \mathrm{G}$} \\
\hline & GI & \multicolumn{2}{|l|}{ AA } & GI & $\mathrm{AA}$ \\
\hline 2 weeks & $3.82 \pm 0.831$ & \multicolumn{2}{|c|}{$43.72 \pm 0.967$} & $3.96 \pm 0.587$ & $141.77 \pm 1.769$ \\
\hline $4 \quad$ & $5.68 \pm 0.563$ & \multicolumn{2}{|c|}{$51.78 \pm 0.728$} & $5.36 \pm 0.875$ & $143.54 \pm 0.868$ \\
\hline $6 "$ & $8.10 \pm 0.984$ & \multicolumn{2}{|c|}{$55.63 \pm 1.038$} & $11.43 \pm 1.489$ & $157.27 \pm 1.673$ \\
\hline $8 "$ & $5.22 \pm 0.347$ & \multicolumn{2}{|c|}{$53.35 \pm 0.896$} & $9.15 \pm 0.649$ & $153.76 \pm 0.759$ \\
\hline \multicolumn{6}{|l|}{ Table contd. } \\
\hline \multicolumn{2}{|c|}{$\mathrm{MS}+1 \% \mathrm{G}$} & \multicolumn{2}{|c|}{$\mathrm{MS}+1.5 \% \mathrm{G}$} & \multicolumn{2}{|c|}{$\mathrm{MS}+2 \% \mathrm{G}$} \\
\hline GI & AA & GI & AA & GI & AA \\
\hline $7.17 \pm 0.357$ & $147.58 \pm 1.616$ & $9.16 \pm 1.638$ & $160.56 \pm 0.786$ & $8.15 \pm 1.151$ & $151.62 \pm 1.616$ \\
\hline $9.76 \pm 1.589$ & $152.54 \pm 1.073$ & $11.58 \pm 0.897$ & $164.67 \pm 1.628$ & $11.56 \pm 0.303$ & $153.78 \pm 0.778$ \\
\hline $13.87 \pm 0.698$ & $161.62 \pm 0.261$ & $19.68 \pm 0.290$ & $174.23 \pm 1.268$ & $16.76 \pm 0.659$ & $165.76 \pm 1.150$ \\
\hline $11.76 \pm 0.987$ & $157.76 \pm 0.734$ & $16.78 \pm 1.436$ & $165.29 \pm 0.368$ & $13.63 \pm 0.659$ & $156.64 \pm 1.237$ \\
\hline
\end{tabular}

Values are mean \pm SE of 5 replications. GI: Growth indices, AA: Ascorbic acid, G: Glucose, gdw: gram dry weight.

On comparing ascorbic acid content, glucose fed tissues showed the presence of a very high concentration of this acid as compared to various plant parts. The present study also supports that tissue culture-derived material contains free endogenous ascorbic acid in fair amount. P. cineraria is a rich source of vitamin $C$ and recommended for the use as dietary sources of vitamin C. The ascorbic acid content of this plant is comparable to that of citrus fruits. The objectives of this study were to determine the variability in ascorbic acid content of Prosopis cultivars and biosynthetic potentialities of the callus tissues to produce ascorbic acid and promote the application of plant tissue culture technology in the area of the production of metabolites. Although ascorbic acid research has been ongoing for decades, the work in the 
last 5 years has led to a vast increase in authors' understanding of this small and familiar molecule. It is predicted that this trend will continue in future.

\section{References}

Ahmed S and Beigh SH (2009) Ascorbic acid, carotenoids, total phenolic content and antioxidant activity of various genotypes of Brassica oleracea. J. Medical \& Biol. Sci. 3: $1-8$.

Barbara L (1984) Principles of nutrition and diet therapy, USA.

Bhatacharjee SK (2001) Hand book of medicinal plants. Pointer pulblication, Jaipur.

Chinoy JJ (1962) Formation and utilization of ascorbic acid in the shoot apex of wheat as factors of growth and development. Indian J. Plant Physiol. 5: 172-201.

Isherwood FA and Mapson LW (1962) Ascorbic acid metabolism in plants. Part II. Biosynthesis. Ann. Rev. Plant Physiol. 13: 329-350.

Khasgiwal PC, Mishra GG, and Andmithal BM (1969) Studies on Prosopis spicigera gum. Part I: Physico-chemical characters. Indian Journal of Pharmacy. 31: 148-152.

Loewus FA and Kelly S (1991) Identity of L-ascorbic acid formed from D-glucose by strawberry (Fragaria) Nature. 191: 1059-1061.

Marcus R and Couston AM (2000) The vitamins. In: Goodman \& Gilman's (ed) The pharmacological basis of therapeutics, Mcgraw-Hill Co, USA, pp. 1767-1771.

Nag TN and Grover S (1987) Free ascorbic acid from Lycium barbarum L. tissue culture. Ind. J. Bot. 10: 14-16.

Nag TN, Grover S, Tiwari A, and Jit S (1986) Free endogenous ascorbic acid from Zygophyllaceous plants growing in arid zone of Rajasthan. Ind. J. Bot. 9: 112-113.

Okeri HA and Alonge PO (2006) Determination of the ascorbic acid content of two medicinal plants in Nigeria. Pak. J. Pharma. Sci. 19: 39-44.

Rastogi PR and Mehrotra P (1995) Compendium of Indian medicinal plants: A CDRI series, New Delhi.

Sarkiyayi S and Ikioda H (2010) Estimation of thiamin and ascorbic acid contents in fresh and dried Hibiscus sabdarriffa (Roselle) and Lactuca sativa (Lettuce). Adv. J. Food \& Sci. Tech. 2: 47-49.

Singh V, Mathur K, Sethia M, Bhojak S and Nag TN (1990) Ascorbic acid content from some arid zone plants of Rajasthan. Geobios. 17: 35-37.

Singh V and Nag TN (1991) Production of endogenous ascorbic acid from tissue cultures of Abutilon pannosum Forst. J. Phytol. Res. 4: 13-19.

Tyagi S and Nag TN (2002) Endogenous level of ascorbic acid in moth bean cultivar in vivo and in tissue culture. J. Indian Bot. Sci. 8: 94-98.

Williams SR (1989) Nutrition and diet therapy, Times Mirror/Mosby college publishing, USA. 